\title{
Rural Marketing in India-An Over view: Case Study of BSNL Dr N. N. Sharma
}

Associate Professor, Department of Commerce and Management Govt. P.G College Dharmsala, Himachal, India.

\section{ABSTRACT}

The growing complexities in the modern marketing are also generating ample opportunities in the business world and it has become important for the producers of goods and services to tap all such markets where enough untapped potential is available. The dynamic change in the marketing practices and strategies has transformed the marketing environment to a significant extent. To meet the challenge of creation and retention of customers and entry to rural market with good product packages has become need of an hour. On the other hand increased purchasing power of rural customers has attracted the attention of marketers. It requires unique marketing strategy full of client and location oriented involvement of 4A's. Keeping in view the growth and development of rural markets in India which are contributing significantly in the country's GDP and contributes more than $50 \%$ in the total sales of durable and nondurable products. It has become more important to look in to the rural markets with great zeal and enthusiasm.

Organizations need to sustain if effective network is available to adopt neo-marketing strategies to tap such markets available in rural and for flung areas where more than $65 \%$ population is residing with large untapped consumer potential. For this the role of telecom service providers cannot be overlooked. Present paper is an attempt to overview the concept of rural marketing for which marketing strategy with 4-A approach is applied on BSNL one of the leading telecommunication service provider in rural India and to analyze their various marketing strategies adopted for rural customers.
Keywords: GDP: Gross Domestic Product; BSNL: Bharat Sanchar Nigam Limited.

\section{INTRODUCTION}

The growing complexities in the market are giving a way to the development of new marketing trends to persuade customers for purchasing of a product. The dynamic change in marketing practices and strategies have transformed the marketing environment to a significant extent. For example, the new developments in the field o technology have shifted the focus of marketers from brick to click marketing. Organizations need to sustain and grow in the market; therefore, they adopted newly marketing trends for retaining the existing customers and targeting new customers to increase the market share. These recently developed trends also facilitate the organization to reach the target customers in minimum possible time. An organization selects new marketing trends on the basis of nature and usage of products. Such marketing is a process that involves carefully designing, implementing and controlling formulated strategies to facilitate the exchange of goods and services between organizations and customers. It helps an organization in identifying needs and wants of the customers and delivering products that satisfy those needs and wants. Marketing encompasses various activities that are necessary for an organization to make the right kind of product available to the right set of customers at right time at the right place.

In today's aggressively competitive scenario, marketing has become marketing has become one of the most vital organizational functions as it directly influences the profitability of an organization. It also helps an organization in

${ }^{\circ}$ Council for Innovative Research 
maintaining long term and sustainable relationship with customers by fulfilling their demands. It benefits the society by developing competitive environment that helps in lowering prices of desirable products and creating sound product distribution system to supply products across diverse geographic region.

"Marketing is the process of planning and executing the conception, pricing, promotion and distribution of ideas, goods and services to create exchanges that satisfy individual and organizational goals."

\section{OBJECTIVES OF STUDY}

1. To overview the concept of rural marketing in India.

2. To assess the 4A's of rural marketing to penetrate in rural market

3. To analyze the concept of rural marketing in telecom sector with special reference to $\mathrm{BSNL}$

\section{RESEARCH METHODOLOGY}

Paper is mainly based on secondary data available from different published literature and case studies on rural marketing and data is collected from the unstructured questionnaire is collected from various books, journals magazines and various search engines on internet to find relevant data in addition to and TRAI reports and various published sources of BSNL.

\section{RURAL MARKETING}

In today's competitive business world every business organization is interested to tap every untapped market and if we glance on the untapped market the share of rural market is much more than the urban market. This is the reason that every enterprise is penetrating on rural market due to large consumer base and factors like increase in the purchasing power parity, better communication link, improved infrastructure and positive change in socio economic condition of the rural population. It is more important for every organization to understand the relevance of rural marketing in addition of strategies which are suitable for rural market. This paper discusses about the successful marketing strategies used by a leading telecom company, Bharat Sanchar Nigam Limited' to explore and penetrate the rural market. Due to drastic change in the importance of rural market, the rural market which was totally unorganized, unstructured and uninterested for producers and service providers has become their target market to grow and expand. It has become one of the most important marketing strategies for various Indian and multinational companies. About $68 \%$ of India's population lives in rural areas. Rural population has grown by $12 \%$ in last decade. Rural market has distinguished characteristics, accounts for $40 \%$ of Indian economy. Rural India has huge, heterogeneous and growing consumer market, which contributes more than $50 \%$ to India's total consumer market size.

Rural India has witnessed significant development in last decade, with commitment of financial resources and launch of a range of programmes by government towards physical and social infrastructure development. The report elaborates the status of rural India's infrastructure, social development, living conditions, economy and industry. The Rural India Report enables ruralurban comparisons, study trend of rural statistics over time and gives long term projection essential for market planning. Also, there are detailed state level tables in annexure on each subject covered in the report. Finally, the Report helps in breaking the myths and common perceptions on rural India, with robust facts and figures.

Each and every company today wants to penetrate rural market due to its untapped large consumer base and factors like increase in PPP (Purchasing Power Parity), better road conditions, improved infrastructure and positive change in socio economic conditions of the rural people. Proper understanding and use of rural marketing mix strategies is very essential to penetrate the rural market. This paper discusses about the successful marketing strategies used by different telecom companies and financial service companies to explore and penetrate the rural market. Marketing 
strategies are the key to and company's growth and success. Rural market is different. It needed special focus and completely different strategies. Indian rural market has seen a drastic change in the last 10 years. A decade ago rural market was unorganized, unstructured and not even companies were seriously interested to explore the opportunities in rural market. Now situation has changed and companies are concentrating and seeing rural market as an interim part of business. Now tapping the rural market is one of the most important marketing strategies for various Indian and multinational companies. After success of FMCG giants HUL (Project Shakti) and ITC (eChoupal) in tapping rural markets telecom sector companies, financial services companies and consumer durable companies are adopting successful strategies to penetrate the rural market. Every company has used unique and completely different marketing strategies to tap rural market.

This paper also discusses about some successful strategies of companies by engaging rural consumers in product development to win the rural market. Here rural consumer engagement means to take the feedback about the problems faced by consumers in using existing product.

\subsection{Rural marketing from the past (Yesterday's strategies)}

Before 1960s rural marketing was known as marketing of rural and agro products to rural markets and urban markets. Agro product lie cotton, food grains and sugarcane were the primary products marketed in the past. Scope of farm equipment such as tractors, pumps sets, thrashers and pesticides, seeds and fertilizers was very limited. Rural market was totally organized so there were no specific marketing strategies were prepared by the marketers. Rural marketing was synonymous with agricultural marketing.

After green revolution scope of rural marketing get widen due to turning of poverty stricken villages turned into cash rich centers. The demand for agri-input product such as fertilizer, pesticides, better variety seeds, tractors, tillers, harvesters, water pumps and spriklers rises due to the positive result of green revolution. Now scope of agricultural marketing extends form 'agricultural marketing' to 'marketing of agricultural inputs'. Companies like Mahindra \& Mahindra, IFFCO, Eicher, Sriram fertilizers and Escorts were emerged due to this drastic change.

\subsection{Present scenario of rural marketing (Today's strategies):}

Today, rural marketing is marketing of consumer product, durable products, automobile products, telecommunication and financial services along with agricultural inputs in rural areas. Rural marketing is in its developmental phase and future market for the survival of mot of the companies. The reason behind this change is there:

- Socio - economic changes (lifestyle, habits and tastes, economic status)

- $\quad$ Literacy level (25\% before independence more than $65 \%$ in 2001$)^{*}$

- Infrastructure facilities (roads, electricity, media)

- Increase in income

- Increase in expectations

- Urban market is saturated

- Huge potential of rural market is now visible

Now rural marketing represents the emergent distinct activity $f$ attracting and servicing rural markets, fulfill the needs and wants to persons, households and occupations of rural people.

\section{RURAL MANAGEMENT \\ MARKETING}

The increased purchasing power of rural customers has attracted the attention of urban marketers. After green revolution, the rural market started consuming a significant quantity of products manufactured in urban and industrial areas. Thus, the marketers have made special marketing strategies to enter the rural market by offering the product in smaller quantities and promoting it in regional languages. Further, these strategies emerged as a concept of rural marketing, which is different from agricultural marketing. Rural marketing involves the process of delivering products that are manufactured in 
urban areas to rural customers. However, agricultural marketing involves delivering agriculture products manufactured in rural areas to urban customers. For example, electronic gadgets are manufactured in urban areas and also delivered to rural areas. On the other hand, crops are manufactured in rural areas and delivered to urban areas.

In rural areas, the products are distributed through wholesalers, retailers, and unconventional distribution channels. For example, Hindustan Unilever used an unconventional channel, such as Shakti to widen the scope of distribution in rural areas. Marketers need different strategies to enter the rural market. The strategies include the following considerations:

Client and Location Specific Promotion: Refers to the strategy designed to suit a particular location and clients

Joint or Cooperative Promotion: Implies that strategy involves participation between marketers and rural clients

Bundling of Inputs: Includes the sale of various related items to rural customers or clients by the marketers. It also includes after sale and credit arrangement service.

Management of Demand: Includes continuous market research of needs and problems of buyers for continuous improvement and innovation to sustain in the market.

Unique Selling Proposition (UPS): Presents a unique feature of product to attract rural customers to buy the product.

Extension Services: Refer to provide additional services, such as providing training to rural customers to use the products

Partnership for Sustainability: Refer to utilize the relationship for long and continuous business with rural customers.

Now, let us discuss the 4A's of rural marketing

\section{FOUR A's OF RURAL MARKETING}

The Indian rural market contributes $50 \%$ in the total sales of durable and nondurable products. For Fast Moving Consumer Goods (FMCG) products, the Indian rural market is growing faster than the urban market. The four As of rural marketing is similar to marketing mix. The four A's of rural marketing are as follows:

i) Affordability: Refers to the ability of customers to pay for the product. The price of products should be set to match the income level of rural customers. Affordability does not mean that the marketer should provide cheaper products but the product should be brought into the range of ability to pay. The income of rural population is less than urban population so they cannot invest a large sum on a single product. Therefore, rural population prefers to buy small quantity of products, which are affordable for them. For example, small recharge coupons worth Rs 10, 20 ,30 launched by BSNL is marketing strategy to make their products affordable.

ii) Availability: Refers to the reach of a distribution channel in the rural market. Distribution is the biggest problem of the rural market due to lack of transportation facilities. In rural areas, retailers maintain good relationships with customers; therefore, it takes less time to sell a new product. An organization should adopt the best distribution channel to reach the rural market with minimum cost possible. For example BSNL has made its products available through private vendors also to make it available at the door steps of rural population.

iii) Awareness: Refers to promotional activities to provide information to customers. The best media to reach the rural market are TV and radio. The other unconventional channels can be used to provide information, such as e-Choupal by ITC. The organization should conduct awareness programs in local languages to convey the message. Philips India used radio and wall writing to reach the Indian rural market. In addition to this advertisement hoardings, TV channels with effective advertising message like Hindustan bol raha hai etc are the strategies adopted to make customers aware about products.

iv) Acceptability: Implies that a product should be readily acceptable by rural customers. Marketing mix should be properly designed to suit the rural customers. BSNL has announced number

${ }^{\circ}$ Council for Innovative Research

195 | P a g e 
of annual tariff plans for its rural clients like annual rental plan of Rs 600 , due to which its products are easily acceptable rural market.

\subsection{Scope of Rural Marketing in India}

Over the last few decades, the Indian rural market has become prominent due to growth in the purchasing power, of rural population. The rural areas consume a large quantity of products manufactured in urban areas; therefore, the rural market is getting more importance than urban market. Nowadays, the marketers are looking for expansion in the untapped rural market .The majority of Indian population lives in rural areas; therefore, there is a vast scope for marketing in rural India. An organization follows rural marketing for the following reasons:

- Rural Population: Consists of more than 720 million people and forms a huge market for organizations.

- Rural Economy: Contributes significantly in the country's GDP. Rural India has a large number of households who are aware about the branded products and willing to buy them.

Relation between Rural and Urban Economy: Refers to economic connectivity between rural and urban areas.

\section{PROFILE OF BHARAT SANCHAR NIGAM LIMITED}

\subsection{Origin}

BSNL then known as the Department of Telecommunications had been a near monopoly during the socialist period of the Indian economy. During this period, BSNL was the only telecom service provider in the country. MTNL was present only in Mumbai and New Delhi. During this period BSNL operated as a typical state-run organization, inefficient, slow, bureaucratic, and heavily unorganized. As a result subscribers had to wait for as long as five years to get a telephone connection. The corporation tasted competition for the first time after the liberalization of Indian economy in 1991. Faced with stiff competition

${ }^{\circ}$ Council for Innovative Research from the private telecom service providers, BSNL has subsequently tried to increase efficiencies itself. DoT veterans, however, put the onus for the sorry state of affairs on the Government policies, where in all state-owned service providers were required to function as mediums for achieving egalitarian growth across all segments of the society. The corporation (then DoT), however, failed to achieve this and India languished among the most poorly connected countries in the world. BSNL was born in 2000 after the corporatization of DoT. The corporatization of BSNL was undertaken by an external international consulting team consisting of a consortium of A.F.Ferguson \& Co, JB Dadachanji and NM Rothschild - and was probably the most complex corporatization exercise of its kind ever attempted anywhere because of the quantum of assets (said to be worth USD 50 Billion in terms of breakup value) and over half a million directly and indirectly employed staff. Satish Mehta, who led the team later confessed that one big mistake made by the consortium was to recommend the continuation of the state and circle based geographical units which may have killed the synergies across regions and may have actually made the organization less efficient than had it been a seamless national organization. Vinod Vaish, then Chairman of the Telecom Commission made a very bold decision to promote younger talent from within the organization to take up a leadership role and promoted the older leaders to a role in licensing rather than in managing the operations of BSNL. The efficiency of the company has since improved, however, the performance level is nowhere near the private players.

Bharat Sanchar Nigam Limited (BSNL) was formed on 1st October 2000 by corporatization of the erstwhile Department of Telecom Operations and Department of Telecom Services. The company has taken over the erstwhile functions of the Department of Telecom in respect of provision of telecom services across the length and breadth of the country excluding Delhi and Mumbai. BSNL has a large base of skilled work force of around 2.71 lakh as on $31^{\text {st }}$ December 2011 and is a $100 \%$ Govt. of India owned Public

$$
196 \text { | P a g e }
$$


Sector Undertaking .BSNL is a technologyoriented company and provides all types of telecom services namely telephone services on landline, WLL and GSM mobile, Broadband, Internet, leased circuits and long distance telecom Service. The company has also been in the forefront of technology with $100 \%$ digital new technology switching network. BSNL's nationwide telecom network covers all District headquarters, Sub-Divisional headquarters, Tehsil headquarters and almost all the Block Headquarters.

\subsection{Growth \& Development}

BSNL had 1197.66 lakh Customers as on 31.12.2011. During 2011-12 (up to 31.12.2011), it has added 27.07 lakh customers. As on 31.03.2011, BSNL had 37,963 wired line telephone exchanges with equipped capacity 444.80 lakh lines and customers base 252.25 lakh. The wired line status as on 31.12.2011 is 37,653telephone exchanges with equipped capacity of 431.24 lakh lines and 230.04 lakh connections .BSNL had 862.69 lakh GSM Mobile connections as on 31.03.2011. During 2011-12 (up to31.12.2011), it has added 61.59 lakh GSM Mobile connections raising the GSM Mobile customer base to 924.28 lakh as on 31.12.2011.There were 55.65 lakh WLL connections as on 31.03.2011. The number of connections declined to 43.34 lakh as on 31.12.2011.BSNL provides high speed Broadband (DSL) services and has 74.91 Lakh Broadband connections as on 31.03.2011. During 2011-12 (up to 31.12.2011), it has added 10.81 lakh broadband connections raising the broadband connections to 85.72 Lakh as on 31.12.2011.BSNL is an Internet Service Provider (ISP) and provides a full range of Internet services for which it has established National Internet Backbone (NIB). As on 31.03.2011, BSNL had provided 36.78 lakh Internet connections. The number of internet connections declined 35.76 lakh as on 31.12.2011.

\subsection{BSNL \& Rural areas}

The total number of rural telephones as on 31.03 .2011 was 414.14 lakh (i.e. about $35.38 \%$ of total telephones). During 2011-12 (upto 31.12.2011), it has added 1.86 lakh rural telephones. As on31.12.2011, there were 416.32 lakh rural telephones of BSNL (i.e. about $34.73 \%$ of total telephones).BSNL provided Village Public Telephones (VPTs) in 5.75 lakh villages, up to 31.03 .2011 , out of 5.94villages in the country as per census 2001. During 2011-12, it has covered 797 more villages up to 31.12.2011.

.The corporation remains heavily unionized and is comparatively slow in decision making and its implementation, which largely acts at the instances of unions without bothering about outcome. Management has been reactive to the schemes of private telecom players. Though it offers services at lowest tariffs, the private players continue to notch up better numbers in all areas, years after year. BSNL has been providing connections in both urban and rural areas. Preactivated Mobile connections are available at many places across India. BSNL has also unveiled cost-effective broadband internet access plans (Data One) targeted at homes and small businesses. At present BSNL enjoys around 60\% of market share of ISP services.

\subsection{BSNL \& Year of Broadband 2007}

2007 was declared as "Year of Broadband" in India and BSNL announced plans for providing 5 million broadband connectivity by the end of 2007. BSNL upgraded Data one connections for a speed of up to $2 \mathrm{Mbit} / \mathrm{s}$ without any extra cost. This $2 \mathrm{Mbit} / \mathrm{s}$ broadband service was provided by BSNL at a cost of just US\$ 11.7 per month (as of 21 July 2008 and at a limit of 2.5GB monthly limit with $0200-0800 \mathrm{hrs}$ as no charge period). Further, BSNL is rolling out new broadband services such as triple play. BSNL planned to increase its customer base to 108 million customers by 2010 . With the frantic activity in the communication sector in India, the target appears achievable. BSNL is a pioneer of rural telephony in India. BSNL has recently bagged $80 \%$ of US\$ $580 \mathrm{~m}$ (INR 2,500 crores) Rural Telephony project of Government of India. On 20March 2009 BSNL advertised the launch of BlackBerry

${ }^{\circ}$ Council for Innovative Research 
services across its Telecom circles in India. The corporation has also launched $3 \mathrm{G}$ services in select cities across the country. Presently, BSNL and MTNL are the only players to provide 3G services, as the Government of India has completed auction of $3 \mathrm{G}$ services for private players. BSNL shall get $3 \mathrm{G}$ bandwidth at lowest bidder prices of Rs 18,500 crore, which includes Rs 10,186 crore for $3 \mathrm{G}$ and Rs 8313 crore for BWA.

As of December 2011, many other private operators have started rolling out their 3rd Generation(aka 3G) services alongside and are enjoying some success in their campaigns to get market share. While BSNL still maintains its connectivity standard and expands to many more areas including rural areas with their $3 \mathrm{G}$ services. Also the network infrastructure has been upgraded from to provide $3.6 \mathrm{Mbit} / \mathrm{s}$ to $7.2 \mathrm{MBits} / \mathrm{sec}$. It is enjoying a slow but somewhat steady success in gaining market share in this regard.

The introduction of MNP(Mobile Number Portability) which is an service that lets the consumer change wireless service providers while retaining their actual mobile number, BSNL has seen many customers opting for this service to move away from the services to other operators. Despite this as the Indian Wireless market grows BSNL still has a loyal base of subscribers and many more subscribers being added to it every day. India has the fastest growing telecom network in the world with its high population and development potential in rural and urban areas.. However, rural India still lacks strong infrastructure. India's public sector telecom company BSNL is the 7th largest telecom company in world.

The mobile tele-density has increased to $76.68 \%$ in May 2012. In the wireless segment, 8.35 million subscribers were added in May 2012. The wire line segment subscriber base stood at 31.53 million. Indian telecom operators added a staggering 227.27 million wireless subscribers in the 12 months between Mar 2010 and Mar 2011 averaging at 18.94 million subscribers every month.

${ }^{\circ}$ Council for Innovative Research

\subsection{Internet Users in Rural India}

Internet and Mobile association of India has released stats regarding the internet penetration in Rural India. From a Digital Marketers point of view their numbers come in handy as most of the brands are shifting their focus to rural India.

The research shows that there is high level of ignorance about internet in Rural India and the graph below shows the various reasons for not using the internet in rural India.

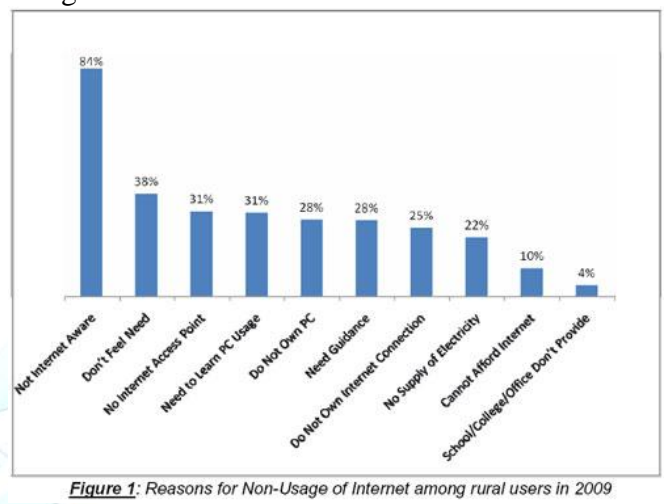

The rural India does not have gadgets to access internet and their main access points of internet being internet café s, home, schools, colleges, offices, computer institutes and block tehsil offices The rise in the internet user in India can rise upto $98 \% 24$ million by end of 2011 compare to 12.1 million in 2010. And the claimed internet user can grow upto impressive $96 \%$ to 29.9 million by Dec 2011 compare to 15.2 million Dec 2010.Mobile phones are already in use by many rural areas and by the introduction of VAS service by Reliance added more subscribers to it. India's major population resides in rural areas. Therefore, they can become maximum consumers of internet India in coming years. An inflection point of internet media.

\section{CONCLUSION}

Rural market is having huge potential in Indian market and more than $65 \%$ population is residing in rural areas which require proper attention, effective strategy and wide marketing network. 
No single marketing strategy can be suitable for rural and urban market due heterogeneous in nature. Different strategies are required for different products from application point of view. Even most established rural marketing 4As approach is adopted in different manner by the two parallel service providers. Although BSNL is adopting this 4As approach in its rural market with very few incentives for rural customers but no separate and effective strategy is undertaken for rural India where there is enough scope because large part of rural market is still untapped and requires separate strategy to compete with other service providers like Airtel, Vodafone, Relaince etc. On the other hand it is need of an hour that BSNL should come forward in rural India with different products of small values and effective connectivity. Engagement of rural customers in product development is equally important for BSNL to innovate and provide better products with effective services.

\section{REFERENCES}

[1] Prof. P.K.Chopra, Bhawana Mehra \& Kogent Learning solutions Inc. Marketing management Dreamtech press New Delhi.

[2] Krishnamacharyulu C.S.G. and ramakrishnan,2008. Rural Marketing: Text and cases, Dorling kindersly (India)Pvt Ltd.

[3] www.indiaretail marketing.com

[4] www.scribed.com/project report on rural marketing

[5] Datt and sundheram ,Indian Economy, S.Chand \&company New Delhi.

[6] Proceedings of National conference on marketing , 2011 asia Pacific Institute of Management New Delhi.

[7] Telephone Regulatory Authority of India Report 2011-12

[8] www.bsnl.com

[9] Indian Economy $2011 \mathrm{~S}$ chand \& company New Delhi

[10] India 2012 Programmes and policies Nov2011
[11] The Indian economy unique publishers New Delhi

[12] Reforms 2020 The Financial Express Nov 2011. 